\title{
The reality of the organizational structure of the Ministry of Youth and Sports
}

\author{
PROF. DR / Metwally Abd Elhamed \\ PROF. DR / Lila Osman Ebrahim \\ PROF. DR / Nahed Ismaail Mohamed \\ Researcher / Zainab Hamed Abdul Hamid Al-Abbadi
}

\section{$\underline{\underline{\text { Introduction and research problem }}}$}

During the past years, the sports industry has witnessed an amazing development in management systems and has become dependent on the philosophy of the capitalist system by providing a spirit of competition and innovation under the supervision of the state to guide the use of available resources, whether (Material, human) and being able to invest in new or existing projects in an effective manner .

Objective : To study the reality of the organizational structure of the Ministry of Youth and Sports .

The question :What is the reality of the organizational structure of the Ministry of Youth and Sports?

\section{Search procedures-:}

Research methodology :The researcher used the descriptive method for the survey, analytical and critical studies and the case study for his suitability of the research topic.

Research community :The researcher determined the basic research population and sample of the managers and specialists of different degrees (Third - Second - First - Senior Researcher - Department Managers ) from the concerned central departments and establishments affiliated to the Ministry of Youth and Sports and the most in contact with the preparation and implementation of sports and investment projects, numbering 490 individuals

\section{The research sample:}

- The basic research sample was randomly chosen from among the constituent groups of the research community and a total of 180 individuals with different degrees and with a percentage of $36.7 \%$.

- The basic research sample was randomly chosen from among the constituent groups of the research community and a total of 150 individuals with different degrees and with a percentage of $83.3 \%$.

- The exploratory research sample was randomly chosen from among the constituent groups of the research community and outside the main sample and its total is 30 individuals with different degrees and with a percentage of $16.6 \%$. 


\section{Table( 1 )}

\section{Classification of the population and research sample categories}

\begin{tabular}{l|c}
\multicolumn{1}{c|}{ The name of the administration } & the number \\
\hline $\begin{array}{l}\text { Specialist managers and the E .da RA Central Sports Investments } \\
\text { Managers and specialist of the Central Administration for Control } \\
\text { and Standards }\end{array}$ & $\mathbf{6 0}$ \\
\hline $\begin{array}{l}\text { Managers and central management specialist for sports development } \\
\text { programs }\end{array}$ & 85 \\
\hline $\begin{array}{l}\text { Managers and specialist of the central administration for financial } \\
\text { affairs }\end{array}$ & 75 \\
\hline $\begin{array}{l}\text { Managers and general administration specialist for sports talent } \\
\text { programs }\end{array}$ & 15 \\
\hline $\begin{array}{l}\text { Managers and sports facilities specialist of the Ministry of Youth and } \\
\text { Sports }\end{array}$ & 45 \\
\hline Sports stadium directors & 25 \\
\hline Open stadium managers & 30 \\
\hline Covered hall managers & 40 \\
\hline Swimming pool managers & 35 \\
\hline
\end{tabular}

\section{Data collection tools : The researcher used the data collection in this research with the following tools:}

1- Documents and records : References scientific, previous studies (Arab , foreign ) records and documents the Ministry of Youth and Irrigation intifada related to the topic of research in order to identify the extent of the application of the reality of the organizational structure of the Ministry of Youth and Sports, the Executive Plan of the Ministry of $2019 \mathrm{~m} / 2020$

2- Personal interview : The researcher conducted some unconverted personal interviews with some leaders, ministry agents, managers, sports specialists, and technical experts at the Ministry of Youth and Sports as well as sports facilities of the Ministry of Youth and Sports in order to support the questionnaire procedures and the dimensions and expressions it contained.

3- The questionnaire :The researcher designed a questionnaire entitled (The reality of the organizational structure of the Ministry of Youth and Sports (and its dimensions) the reality of the competencies in the organizational structure, the restructuring of financial resources, the restructuring of activities and operations, the restructuring of activities and services) with the aim of studying the reality of the organizational structure of the Ministry of Youth and Sports 


\section{Steps to build the survey:}

1- Determining the goal of the questionnaire : Study the reality of the organizational structure of the Ministry of Youth and Sports .

2- Reading and reading : reviewing previous Arab and foreign scientific studies and research related to the research topic.

3- Determine the dimensions of the questionnaire : was determined the dimensions of the key for E Stmarh E .questionnaire " the reality of the organizational structure of the Ministry of Youth and Sports "and consisted in four dimensions ) the reality of the terms of reference to the organizational structure, the restructuring of financial resources, restructuring activities and operations, restructuring activities and services)

\section{4- Formulate the phrases for the questionnaire :}

The drafting of phrases form questionnaire Jan through the practice of references and previous studies of the scientific method and then define a set of phrases that Taburan each after the E. Stmarh questionnaire with a total number (4) dimensions and the total number( 21 ) words have been subject to follow the scientific method that bear the phrase meaning One

\section{5- Presenting the questionnaire to the experts- :}

The questionnaire was presented to the experts to identify the approval percentage of a group of academic experts from university professors in the field of sports management, as well as a group of executive experts from the leading cadres in the Ministry of Youth and Sports with a total of (15) experts from 2019/4/1 to 3/7 / 2019 in order to express an opinion or delete or amend what they see as appropriate in the proposed scale of assessment and also to achieve the following :

- The adequacy of the proposed dimensions to achieve the research objectives.

- The suitability of the phrases under each dimension and phrase

- Add what they deem appropriate from the dimensions and phrases.

- Delete what they deem inappropriate from the dimensions and phrases.

- Arrange dimensions and phrases according to their importance.

- Determining the proposed estimate scale for the questionnaire.

\section{Conditions for selecting experts- :}

1- Academic experts :To be one of the professors of the faculty members, as their experience is not less than 25 years in the academic field of sports management . 
2- Executive Experts :Sports administrative cadres where their experience is not less than 25 years in the administrative and vocational field at the Ministry of Youth and Sports.

In light of the agreement of the academic and executive experts, who number (15 (on the dimensions under which the phrases related to the questionnaire are concerned, the researcher has satisfied $80 \%$ or more of the acceptance

After presenting the questionnaire in its initial form to the experts, the researcher calculated the percentage of the opinions of the experts in the dimensions and the default phrases of the questionnaire

Table ( 2 )

The percentage of expert opinions on the dimensions of a questionnaire "The reality of the organizational structure of the Ministry of Youth and Sports " ( $\mathbf{N}=\mathbf{1 5})$

\begin{tabular}{c|l|c|c}
\hline $\mathrm{M}$ & \multicolumn{1}{|c|}{ The hubs } & Repeat approval & \%Relative weight \\
\hline 1 & $\begin{array}{l}\text { The reality of the terms of reference in the } \\
\text { organizational structure }\end{array}$ & th15 & $\% 100$ \\
\hline 2 & $\begin{array}{l}\text { Restructuring of financial resources, restructuring of } \\
\text { activities and operations }\end{array}$ & th15 & $\mathbf{1 0 0 \%}$ \\
\hline 3 & Restructuring activities and services & th15 & $100 \%$ \\
\hline
\end{tabular}

The questionnaire is in its initial (initial) form:

The researcher has formulated expressions of the questionnaire form, and the number of expressions of the questionnaire form has total number (23) A phrase where it was distributed as follows $\otimes$ The first dimension : the reality of terms of reference in the structure Organizational, the after second :the restructuring of financial resources, the third dimension :the restructuring of the activities and operations, The fourth dimension :restructuring activities and services)

The questionnaire was presented in its initial form to the experts to express their opinion on an appropriate extent

The proposed dimensions and phrases, deletion or amendment, and adding what the expert experts deem appropriate, and Table (3) shows the percentages of experts' opinions on the proposed dimensions and phrases.

Table ( 3 )

Frequencies and percentages of expert opinions about dimensions and phrases of a questionnaire " The reality of the organizational structure of the Ministry of Youth and Sports" $(\mathbf{N}=15)$

The first dimension: the reality of the specialties in the organizational structure (job description

\begin{tabular}{c|c|c}
\hline$M$ & $T$ & Relative weight $\%$ \\
\hline 1 & 15 & $\% 100$ \\
\hline 2 & 15 & $\% 100$ \\
\hline 3 & 12 & $\% 80$ \\
\hline 4 & 15 & $\% 100$ \\
\hline
\end{tabular}




\begin{tabular}{c|c|c}
\hline 5 & 15 & $\% 100$ \\
\hline \multicolumn{2}{|c|}{ The second dimension: the restructuring of financial resources } \\
\hline 6 & 15 & $\% 100$ \\
\hline 7 & 15 & $\% 100$ \\
\hline 8 & 14 & $\% 93.3$ \\
\hline 9 & 15 & $\% 100$ \\
\hline 10 & 14 & $\% 93.3$ \\
\hline \hline
\end{tabular}

\section{Continued Table( 3 )}

Continued Frequencies and percentages of expert opinions about dimensions and phrases of a

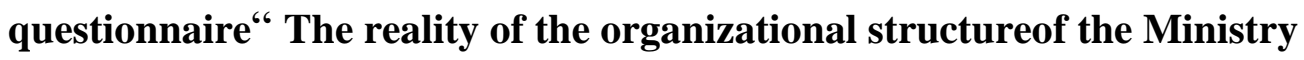
of Youth and Sports"

$(\mathbf{N}=15)$

\begin{tabular}{c|c|c}
\hline \hline & The third dimension: restructuring activities and operations & \\
\hline 11 & 11 & $\% 73.3$ \\
\hline 12 & 15 & $\% 100$ \\
\hline 13 & 15 & $\% 86.67$ \\
\hline 14 & 13 & $\% 100$ \\
\hline 15 & 15 & $\% 13.3$ \\
\hline 16 & 11 & $\% 0$ \\
\hline 17 & 15 & $\% 86.67$ \\
\hline \multicolumn{2}{|c|}{ The fourth dimension: restructuring activities and services } \\
\hline 19 & 15 & $\% 100$ \\
\hline 20 & 13 & $\% 80$ \\
\hline 21 & 15 & $\% 100$ \\
\hline 22 & 12 & 100 \\
\hline 23 & 15 & 15 \\
\hline \hline
\end{tabular}

It is clear from Table (3) that: The result of the expert opinion poll on the dimensions and phrases of the questionnaire and the reality of the organizational structure of the Ministry of Youth and Sports (23) indicated that the majority of experts agreed on the dimensions and phrases of the questionnaire, where approval rates ranged between $(80 \%-$ $100 \%$ ) and thus (22) phrases related to the dimensions and phrases of the form were accepted, and a number of (1) phrases were excluded, whose approval rate is less than (80\%) which is No. (11)

\section{Scientific transactions for the questionnaire (honesty ) - :}

\section{1- Validate content (content) :}

The dimensions and terms of the questionnaire were presented to the experts) academics, executives (from university professors in the field of sports management, as well as a group of executive experts from the leading cadres in charge of the Ministry of Youth and Sports, and they were a total of (15) experts. Table (2) showed the percentages of experts agreeing on dimensions And questionnaire phrases

\section{2- Internal consistency validity:}

To calculate the honesty of the questionnaire form, the researcher used the validity of the internal consistency by applying the form to the survey sample and they are (30) 
individuals from the research community and outside the basic sample by calculating the correlation coefficients between the degree of correlation of each phrase and the dimension to which it belongs

Table ( 4 )

Correlation coefficients between phrases and the sum of each dimension of a questionnaire "The reality of the organizational structure of the Ministry of Youth and Sports "

$(\mathbf{N}=30)$

\begin{tabular}{|c|c|c|}
\hline \multicolumn{3}{|c|}{ The first dimension: setting goals Alparw } \\
\hline Phrase & Correlation coefficients & Significance level \\
\hline 1 & $\mathbf{0 . 6 2 0}$ & $* * 00.0$ \\
\hline 2 & 0.553 & $* * \mathbf{0 . 0 0}$ \\
\hline 3 & 0.460 & ** 010.0 \\
\hline 4 & 0.693 & $* * \mathbf{0 . 0 0}$ \\
\hline 5 & 0.485 & $* * 30.00$ \\
\hline \multicolumn{2}{|c|}{ Moral $0.05 *$} & Moral $0.01 * *$ \\
\hline \multicolumn{3}{|c|}{ The second dimension: the restructuring of financial resources } \\
\hline 6 & $\mathbf{0 . 5 5 5}$ & $* 020.0$ \\
\hline 7 & 0.499 & * 300.0 \\
\hline 8 & 0.575 & $* * 0.001$ \\
\hline 9 & 0.592 & $* * \mathbf{0 . 0 0}$ \\
\hline 10 & 0.901 & * 0.00 \\
\hline \multicolumn{2}{|c|}{ Moral $0.05 *$} & Moral $0.01 * *$ \\
\hline \multicolumn{3}{|c|}{ The third dimension: restructuring activit } \\
\hline 11 & 0.561 & $* * 0.001$ \\
\hline 12 & 0.630 & $* * 0.00$ \\
\hline 13 & 0.562 & *0.002 \\
\hline 14 & 0.653 & $* * 0.002$ \\
\hline 15 & 0.591 & $* * 0.00$ \\
\hline \multicolumn{2}{|c|}{ Moral $0.05 *$} & Moral $0.01 * *$ \\
\hline \multicolumn{3}{|c|}{ The fourth dimension: restructuring activities and services } \\
\hline 16 & $\mathbf{0 . 5 9 8}$ & * 020.0 \\
\hline 17 & 0.590 & * 300.0 \\
\hline 18 & 0.715 & $*$ * 0.003 \\
\hline 19 & $\mathbf{0 . 8 8 3}$ & $* * \mathbf{0 . 0 0}$ \\
\hline 20 & 0.663 & $* * 0.00$ \\
\hline 21 & 0.560 & **010.0 \\
\hline \multicolumn{2}{|c|}{ Moral $0.05 *$} & Moral $0.01 * *$ \\
\hline
\end{tabular}

Seen from the table (4) that : the correlation coefficients between the degree of each phrase and the dimension of a belong enjoys correlation coefficients strong and statistically significant, and thus become a questionnaire Form in its final form distributed on four dimensions of the total number (21) is a

In order to achieve the stability of the questionnaire, the researcher used the (Fakronbach) laboratories by applying the form to the survey sample and its number is 30 individuals from the research community and outside the basic sample. 
Table (5)

Stability coefficient of a questionnaire " The reality of the organizational structure of the Ministry of Youth and Sports"

\begin{tabular}{c|l|c}
\hline \hline$M$ & \multicolumn{1}{c|}{ Statement } & the value \\
\hline 1 & Correlation coefficient between the two parts & 0.901 \\
\hline 2 & Gitman lab & 0.942 \\
\hline 3 & Alpha coefficient of the first part & 0.911 \\
\hline 4 & Alpha coefficient of the second part & 0.931 \\
\hline \hline
\end{tabular}

It is clear from the results of Table No (5) : that the stability factor of the questionnaire and the reality of the organizational structure of the Ministry of Youth and Sports came as follows : the correlation coefficient between the two parts with a value of , $(0.901)$ while the Gettman coefficient (0.942), while the alpha coefficient of the first part (0.911) came, while The alpha coefficient came for the second part (0.931) and from the previous values it is clear that the coefficient of persistence of the form using the coefficient of (Alpha Cronbach Alpha ( It came high, which indicates the stability of the form and then its suitability to apply.

\section{Basic study of the research:}

\section{After conducting the scientific transactions for the questionnaire form}

(honesty - consistency) and verifying its suitability to apply to the basic sample for research, the application was carried out from 2019/4/1 to 3/7/2019 and after collecting the questionnaire form it was emptied and the researcher used the balance of the triple estimate of the questionnaire terms so that The positive response takes (Yes) (3) degrees, the response takes (to some extent) (2) degrees, and the response takes (No) (1) degrees to show the reality of the organizational structure of the Ministry of Youth and Sports.

\section{Statistical methods used:}

The data was processed by computer using the statistical packages for social sciences program SPSS V.24, And the following statistical methods have been applied:

( Calculation of iterations, mean, relative weight\%, Pearson correlation coefficient, Alpha Kronbach coefficient )

To achieve the goal of the research and ending to answer questioning and in the limits of the findings of the researcher of the results through the method used and the community and the research sample and tools selected data collection and statistical analysis researcher presented Father results returned and phrases to answer the question of research and discussion Te ( what the reality of the organizational structure of the Ministry of Youth And sports? ) 
Table (6)

The estimated degree and relative weight of the responses of the main research sample to organizational structure reality of the The" diminish a questionnaire

of the Ministry of Youth And sports"

$(\mathrm{N}=\mathbf{1 5 0})$

\begin{tabular}{c|c|c|c|c|l|l}
\hline \hline $\begin{array}{c}\text { the } \\
\text { level }\end{array}$ & Arrangement & $\begin{array}{c}\text { Relative } \\
\% \text { weight }\end{array}$ & $\begin{array}{c}\text { Weighted } \\
\text { average }\end{array}$ & $\begin{array}{c}\text { Estimated } \\
\text { score }\end{array}$ & $\begin{array}{l}\text { Survey dimensions The reality of the : } \\
\text { organizational structure of the Ministry of } \\
\text { Youth and Sports }\end{array}$ & $M$ \\
\hline Guest & 1 & $\% 45.67$ & 1.37 & 1028 & $\begin{array}{l}\text { The reality of the terms of reference in the } \\
\text { organizational structure ( Job Descriptions) }\end{array}$ & 1 \\
\hline Weak & 2 & $\% 42.33$ & 1.27 & 955 & Financial restructuring & 2 \\
\hline Weak & 3 & $\% 41.33$ & 1.24 & 934 & Restructuring of activities and operations & 3 \\
\hline Weak & 4 & $\% 41$ & 1.23 & 1111 & Restructuring of activities and services & 4 \\
\hline Weak & & $\% 42.67$ & 1.28 & $\mathbf{4 0 2 8}$ & The dimension as a whole & 4 \\
\hline \hline
\end{tabular}

Seen from the table (6) that the dimensions and the reality of the questionnaire structure of the organizational Ministry of Youth and Sports v ranged between $(45.67 \%, 41.00 \%)$ and may arrange dimensions as follows came: In the first ranking first dimension and the reality of the terms of reference to the organizational structure (job description) $45.67 \%$ While the second arrangement came after the second dimension restructuring of financial resources $42.33 \%$, while the third arrangement came after the third restructuring of activities and operations $41.33 \%$, while it came in the fourth and final arrangement the fourth dimension restructuring of activities and services $\% 41$

It is clear from the total relative weight $(\% 42.67)$ of the responses of the main research sample that the reality of the organizational structure of the Ministry of Youth and Sports has come at a weak level .

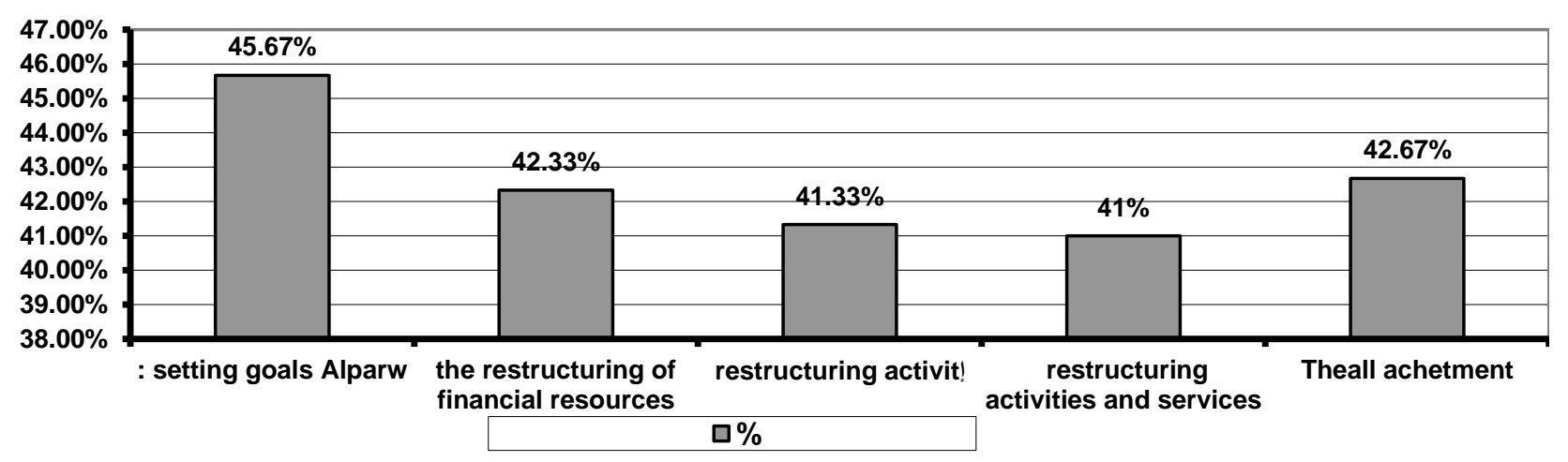

Figure (1)

Discussing the results of dimensions of the questionnaire "The reality of the organizational structure of the Ministry of Youth and Sports" 


\title{
A - Presenting the results of the first dimension : the reality of the specializations in the organizational structure ( job description )
}

\author{
Table(7 )
}

Estimated score and relative weight of basic research sample responses to first dimension phrases " The reality of terms of reference in the organizational structure (job description )

\begin{tabular}{|c|c|c|c|c|c|c|c|c|}
\hline \multirow[b]{2}{*}{$\begin{array}{r}\text { Arrang } \\
\text { ement }\end{array}$} & \multirow{2}{*}{$\begin{array}{l}\text { Relative } \\
\text { \%weight }\end{array}$} & \multirow[b]{2}{*}{$\begin{array}{l}\text { Weighted } \\
\text { average }\end{array}$} & \multirow[b]{2}{*}{$\begin{array}{l}\text { Estimat } \\
\text { ed score }\end{array}$} & \multicolumn{3}{|c|}{ The response } & \multirow{2}{*}{$\begin{array}{l}\text { Phrase } \\
\text { As a specialist in the Ministry of Youth and } \\
\text { Sports, I see that the organizational structure of } \\
\text { the Ministry of Youth and Sports is available in } \\
\text { it }\end{array}$} & \multirow{2}{*}{$\mathbf{M}$} \\
\hline & & & & \begin{tabular}{|l|} 
disagree \\
\end{tabular} & $\begin{array}{c}\text { To } \\
\text { some } \\
\text { extent }\end{array}$ & $\begin{array}{c}\text { I } \\
\text { agree }\end{array}$ & & \\
\hline 1 & $\% 51.33$ & 1.54 & 231 & 94 & 31 & 25 & $\begin{array}{r}\text { Various specialties and departments } \\
\text { concerned according to the nature of the work } \\
\text { (job description) }\end{array}$ & 1 \\
\hline 2 & $\% 47.33$ & 1.42 & 213 & 102 & 33 & 15th & $\begin{array}{r}\text { Flexibility and consistency in policies, rules } \\
\text { and principles of administrative work }\end{array}$ & 2 \\
\hline 5 & $\% 42.00$ & 1.26 & 189 & 118 & 25 & 7 & $\begin{array}{r}\text { Ease of communication and information } \\
\text { exchange between the different administrative } \\
\text { levels (upper, middle, and executive) ) }\end{array}$ & 3 \\
\hline 3 & $\% 44.00$ & 1.32 & 198 & 108 & 36 & 6 & $\begin{array}{r}\text { Clarity of the size of the financial budget and } \\
\text { its distribution according to the needs of the } \\
\text { project }\end{array}$ & 4 \\
\hline 4 & $\% 43.78$ & 1.31 & 197 & 109 & 35 & 6 & $\begin{array}{r}\text { Clarity of time periods for achieving project } \\
\text { objectives and policies }\end{array}$ & 5 \\
\hline & $\% 45.67$ & 1.37 & 1028 & & & & Total & \\
\hline
\end{tabular}

It is clear from Table (7) that the reality of the terms of reference in the organizational structure (job description ) ranges from

$(\% 42.00, \% 51.33)$ The arrangement of the dimension expressions came as follows: At the beginning of the arrangement the various specializations and departments concerned according to the nature of the work (job description) $51.33 \%$, while the second arrangement came flexibility and consistency in the policies, rules and principles of administrative work $47.33 \%$, while it came In the third arrangement, clarity of the size of the financial budget and its distribution according to the needs of the project reached $44 \%$, while in the fourth arrangement came clarity of time periods to achieve the goals and policies of the project $43.78 \%$, while in the fifth and last arrangement came the ease of communication and information exchange between different administrative levels( upper, medium, ) executive $42 \%$.

It is clear from the total relative weight (45.67\%) of the responses of the main research sample that the reality of the specializations in the organizational structure (job description) has come at a weak level 


\section{B - View the results of the third dimension of : restructuring of the financial resources}

Table ( 8 )

Estimated score and relative weight of basic research sample responses to second dimension phrases " Restructuring of financial resources"

\begin{tabular}{|c|c|c|c|c|c|c|c|c|}
\hline \multirow[b]{2}{*}{$\begin{array}{c}\text { Arrang } \\
\text { ement }\end{array}$} & \multirow{2}{*}{$\begin{array}{l}\text { Relative } \\
\text { \%weight }\end{array}$} & \multirow[b]{2}{*}{$\begin{array}{l}\text { Weighted } \\
\text { average }\end{array}$} & \multirow[b]{2}{*}{$\begin{array}{l}\text { Estimate } \\
\text { d score }\end{array}$} & \multicolumn{3}{|c|}{ The response } & \multirow{2}{*}{\begin{tabular}{|c|} 
Phrase \\
As a specialist in the Ministry of Youth and \\
Sports, I see that the organizational structure of \\
: the Ministry of Youth and Sports is available in it
\end{tabular}} & \multirow{2}{*}{$\mathbf{M}$} \\
\hline & & & & $\begin{array}{l}\text { disag } \\
\text { ree }\end{array}$ & $\begin{array}{c}\text { To } \\
\text { some } \\
\text { extent }\end{array}$ & $\begin{array}{c}\text { I } \\
\text { agree }\end{array}$ & & \\
\hline 1 & $\% 44.67$ & 1.34 & 201 & 106 & 37 & 7 & $\begin{array}{r}\text { Covering the budget determined for the project } \\
\text { needs of tools, equipment and others }\end{array}$ & 6 \\
\hline m 1 & $\% 44.67$ & 1.34 & 201 & 104 & 41 & 5 & $\begin{array}{l}\text { The amount of revenue is proportional to the } \\
\text { amount spent on maintenance and operation }\end{array}$ & 7 \\
\hline 2 & $\% 42.67$ & 1.28 & 192 & 111 & 36 & 3 & $\begin{array}{r}\text { Distribution of projects in proportion to the size } \\
\text { and nature of the beneficiaries }\end{array}$ & 8 \\
\hline 3 & $\% 40.67$ & 1.22 & 183 & 120 & 27 & 3 & $\begin{array}{l}\text { Use of modern management systems and } \\
\text { methods in marketing and investment }\end{array}$ & 9 \\
\hline \multirow[t]{2}{*}{4} & $\% 39.56$ & 1.19 & 178 & 127 & 18 & 5 & $\begin{array}{r}\text { Allocation of the budget to train project-based } \\
\text { cadres in accordance with the specializations } \\
\text { assigned to work }\end{array}$ & 10 \\
\hline & $\% 42.33$ & 1.27 & 955 & & & & Total & \\
\hline
\end{tabular}

clear from Table (8) that the reality of restructuring the financial resources in the organizational structure of the Ministry of Youth and Sports ranges from (44.67\% , 39.56\% ) And the arrangement of the dimension expressions was as follows:

Covering the budget determined for the project's needs for tools, equipment, etc., the size of revenue is consistent with the amount spent on maintenance and operation) $44.67 \%$, while the second arrangement came to distribute projects in a manner commensurate with the size and nature of the beneficiaries $42.67 \%$, while in the third arrangement came a use of administrative systems and methods Modern in marketing and investment $40.67 \%$, while the fourth arrangement came to allocate the budget to train project-based cadres in accordance with the specialties assigned to work $39.56 \%$.

It is clear from the total relative weight (42.33\%) of the responses of the basic research sample that the reality of restructuring the financial resources in the organizational structure of the Ministry of Youth and Sports has come at a weak level 


\section{C- Displaying the results of the third dimension: restructuring activities and operations}

Table (9)

Estimated score and relative weight of basic research sample responses to three dimension phrases " Restructuring of activities and operations" $\quad(\mathrm{N}=150)$

\begin{tabular}{|c|c|c|c|c|c|c|c|c|}
\hline \multirow[b]{2}{*}{$\begin{array}{l}\text { Arra } \\
\text { ngem } \\
\text { ent }\end{array}$} & \multirow{2}{*}{$\begin{array}{l}\text { Relative } \\
\text { \%weight }\end{array}$} & \multirow[b]{2}{*}{$\begin{array}{l}\text { Weighted } \\
\text { average }\end{array}$} & \multirow[b]{2}{*}{$\begin{array}{l}\text { Estimat } \\
\text { ed } \\
\text { score }\end{array}$} & \multicolumn{3}{|c|}{ The response } & \multirow[b]{2}{*}{$\begin{array}{l}\text { Phrase } \\
\text { As a specialist in the Ministry of Youth and Sports, I } \\
\text { see that the organizational structure of the Ministry of } \\
-: \text { Youth and Sports is available in it }\end{array}$} & \multirow[b]{2}{*}{$\mathbf{M}$} \\
\hline & & & & $\begin{array}{c}\text { disag } \\
\text { ree }\end{array}$ & $\begin{array}{c}\text { To } \\
\text { some } \\
\text { exten } \\
\text { t }\end{array}$ & $\begin{array}{c}\text { I } \\
\text { agree }\end{array}$ & & \\
\hline 4 & $\% 40.44$ & 1.21 & 182 & 119 & 30 & 1 & $\begin{array}{r}\text { A selection of specialized cadres in proportion to the } \\
\text { size and needs of work in the project }\end{array}$ & 11 \\
\hline 2 & $\% 42.00$ & 1.26 & 189 & 113 & 35 & 2 & $\begin{array}{r}\text { Relevant departments concerned with preparing } \\
\text { feasibility studies for projects }\end{array}$ & 12 \\
\hline m 2 & $\% 42.00$ & 1.26 & 189 & 113 & 35 & 2 & $\begin{array}{r}\text { Specific criteria that correspond to the nature of } \\
\text { work within the organizational structure }\end{array}$ & 13 \\
\hline 1 & $\% 42.22$ & 1.27 & 190 & 112 & 36 & 2 & $\begin{array}{r}\begin{array}{r}\text { Observing specific criteria when choosing leadership } \\
\text { styles that are capable of productivity and } \\
\text { investment }\end{array} \\
\end{array}$ & 14 \\
\hline \multirow[t]{2}{*}{3} & $\% 40.89$ & 1.23 & 184 & 117 & 32 & 1 & $\begin{array}{r}\text { Use the latest methods for training and continuous } \\
\text { development of leaders and specialized cadres }\end{array}$ & 15 th \\
\hline & $\% 41.33$ & 1.24 & 934 & & & & Total & \\
\hline
\end{tabular}

Seen from the table (9) The reality of restructuring activities and operations to the organizational structure of the Ministry of Youth and Sports v ranged between $(42.22 \%$, $40.44 \%$, (and the order came dimension phrases as follows: at the beginning of the order taking into account the specific criteria when selecting patterns of leadership capable of productive investment $42.22 \%$, While it came in the second arrangement, both (concerned departments specialized in preparing feasibility studies for projects, specific criteria that correspond to the nature of work within the organizational structure) $42.00 \%$, while in the third arrangement came the use of the latest methods of training and continuous development of leaders and specialized cadres $40.89 \%$, while it came in The fourth and final arrangement is a selection of specialized cadres in proportion to the size and needs of work in the project $40.44 \%$.

It is clear from the total relative weight $(41.33 \%)$ of the responses of the basic research sample that the reality of the restructuring of activities and operations in the organizational structure of the Ministry of Youth and Sports has come at a weak level. 


\section{D- Presenting the results of the fourth dimension: restructuring activities and services}

(10) Table

Estimated score and relative weight of basic research sample responses to fourth dimension phrases in a form " Restructuring of activities and services" $\quad(N=150)$

\begin{tabular}{|c|c|c|c|c|c|c|c|c|}
\hline \multirow[b]{2}{*}{$\begin{array}{l}\text { Arrang } \\
\text { ement }\end{array}$} & \multirow{2}{*}{$\begin{array}{l}\text { Relative } \\
\text { \%weight }\end{array}$} & \multirow[b]{2}{*}{$\begin{array}{l}\text { Weight } \\
\text { ed } \\
\text { average }\end{array}$} & \multirow[b]{2}{*}{$\begin{array}{l}\text { Estimat } \\
\text { ed } \\
\text { score }\end{array}$} & \multicolumn{3}{|c|}{ The response } & \multirow{2}{*}{$\begin{array}{l}\text { Phrase } \\
\text { As a specialist in the Ministry of Youth and Sports, I see } \\
\text { that the organizational structure of the Ministry of Youth } \\
-: \text { and Sports is available in it }\end{array}$} & \multirow[b]{2}{*}{$\mathbf{M}$} \\
\hline & & & & $\begin{array}{c}\text { disag } \\
\text { ree }\end{array}$ & $\begin{array}{c}\text { To } \\
\text { some } \\
\text { exten } \\
\text { t }\end{array}$ & $\begin{array}{c}\text { I } \\
\text { agree }\end{array}$ & & \\
\hline 3 & $\% 41.33$ & 1.24 & 186 & 116 & 32 & 2 & $\begin{array}{r}\text { Promotional plans for existing projects and appropriate } \\
\text { marketing }\end{array}$ & 16 \\
\hline 1 & $\% 42.44$ & 1.27 & 191 & 113 & 33 & 4 & $\begin{array}{r}\begin{array}{r}\text { Exploiting the potentials and construction spaces and } \\
\text { offering them for investment }\end{array} \\
\end{array}$ & 17 \\
\hline 2 & $\% 41.56$ & 1.25 & 187 & 117 & 29 & 4 & $\begin{array}{r}\text { Continuous development of the activities and services } \\
\text { provided using modern and technological devices }\end{array}$ & 18 \\
\hline 5 & $\% 40.44$ & 1.21 & 182 & 121 & 26 & 3 & $\begin{array}{r}\text { Existence of coordination when making plans through } \\
\text { interim steps }\end{array}$ & 19 \\
\hline 4 & $\% 40.67$ & 1.22 & 183 & 119 & 29 & 2 & $\begin{array}{l}\text { Developing regulations and systems to facilitate the } \\
\text { conduct of administrative, financial and legal work }\end{array}$ & 20 \\
\hline \multirow[t]{2}{*}{ m 5} & $\% 40.44$ & 1.21 & 182 & 119 & 30 & 1 & $\begin{array}{r}\text { Benefiting from the successful administrative } \\
\text { experiences in the private sector in Investing }\end{array}$ & 21 \\
\hline & $\% 41$ & 1.23 & 1111 & & & & Total & \\
\hline
\end{tabular}

Seen from the table (10) that the reality of the restructuring of activities and services to the organizational structure of the Ministry of Youth and Sports v ranged between (42.44\%, $40.44 \%$ ) and came the order of phrases dimension as follows: at the beginning of the order to exploit the potential of construction space and put it up for investment $42.44 \%$, while came in The second arrangement is a continuous development of activities and services provided using modern and technological devices $41.56 \%$, while in the third arrangement came promotional plans for existing projects and their appropriate marketing 41.33\%, while in the fourth arrangement came the development of regulations and systems to facilitate the progress of administrative, financial and legal work $40.67 \%$, while it came in the arrangement Fifth and last: (Coordination exists when developing plans through phased steps, benefiting from successful management experiences in the private sector in investment) $40.44 \%$.

It is clear from the total relative weight $(41 \%)$ of the responses of the basic research sample that the reality of the restructuring of activities and services in the organizational structure of the Ministry of Youth and Sports has come at a weak level

These results are consistent with the study " Yusef Abdullah Al-Azmi 2011 "certainly emphasizing the necessity of an administration concerned with the administrative structure of the authority to prepare feasibility studies for sports and investment projects, which is positively linked to the organizational commitment 
Also, they agree with Nick JohnNick John ,2010 Chu Hyo Shu - HuiPui Lai " 2010that there is a concerned department with specific specialties that clearly works to improve job satisfaction through the diversity of projects and services provided

In this, the researcher may refer to the ambiguity of the various specializations and departments concerned, according to the nature of the work (Job description), nondistribution of projects in a manner commensurate with the size and nature of beneficiaries, poor use of modern administrative systems and methods in marketing and investment Failure to allocate a budget to train project-based cadres in accordance with the specializations entrusted with the work, the absence of specific criteria consistent with the nature of the work within the organizational structure Lack of sophisticated criteria for selecting leadership styles that are capable of productivity and investment

It is clear from the result of the total estimated degree and the relative weight of the dimensions of this questionnaire that the organizational structure of the Ministry of Youth and Sports is of a weak level, where the total relative weight. $\% 41=$

With this ,the research question that states Is answered : ( What is the reality of the organizational structure of the Ministry of Youth and Sports ? ) .

Conclusions: The researcher draws the following conclusions, through which the reality of the organizational structure of the Ministry of Youth and Sports can be studied.

1- The organizational structure of the Ministry of Youth and Sports came at a weak level in terms of terms of reference in the organizational structure, represented by the lack of:

- Clarity of the time periods to achieve the project goals and policies

- Flexibility and consistency in policies, rules and principles of administrative work

- Ease of communication and information exchange between different administrative levels (upper, middle, executive )

- Clarity of the size of the financial budget and its distribution according to the needs of the project

- For the competences of the various departments concerned according to the nature of the job (job description )

2- The organizational structure of the Ministry of Youth and Sports came in at a weak level in restructuring financial resources, represented by the lack of:

- Allocation of the budget to train project-based cadres in accordance with the specializations assigned to work

- Covering the budget determined for the project needs of tools, equipment and others

- Distribution of projects in proportion to the size and nature of the beneficiaries

- Use of modern management systems and methods in marketing and investment 
- It is proportional to the size of revenue with the size spent on maintenance and operation

3- The organizational structure of the Ministry of Youth and Sports came with a weak level in restructuring activities and operations, and is represented by the lack of:

- Use the latest methods for training and continuous development of leaders and specialized cadres

- Relevant departments concerned with preparing feasibility studies for projects

- Specific criteria correspond to the nature of the work within the organizational structure

- Observing specific criteria when choosing leadership styles that are capable of productivity and investment

- A selection of specialized cadres in proportion to the size and needs of work in the project

4- The organizational structure of the Ministry of Youth and Sports came at a weak level in restructuring activities and services, and is represented by the lack of:

- Existence of coordination when making plans through interim steps

- Continuous development of the activities and services provided using modern and technological devices

- Exploiting the potentials and construction spaces and offering them for investment

- Benefiting from the successful management experiences in the private sector in investment

- Developing regulations and systems to facilitate the conduct of administrative, financial and legal work

- Promotional plans for existing projects and appropriate marketing

Recommendations :In the context of what was mentioned in the research and what its procedures contained, and in light of the results and conclusions reached, the researcher extracts some of the important recommendations :

1- The reality of the terms of reference in the organizational structure is that it is necessary to:

- Clarity of the time periods to achieve the project goals and policies

- Flexibility and consistency in policies, rules and principles of administrative work

- Ease of contact and information exchange between different administrative levels (upper, middle, and executive )

- Clarity of the size of the financial budget and its distribution according to the needs of the project

- Defining the powers of the various departments concerned according to the nature of the work (job description ) 


\section{2- Restructuring of financial resources is necessary to:}

- Allocating a budget to train project-based cadres in accordance with the specializations assigned to work

- Determine a budget for the project's needs for tools, equipment, and others

- Distribution of projects in proportion to the size and nature of the beneficiaries

- Use of modern management systems and methods in marketing and investment

- The amount of revenue is proportional to the amount spent on maintenance and operation

\section{3- The restructuring of activities and operations is represented in the necessity of:}

- Using the latest training and continuous development methods for leaders and specialized cadres

- Existence of departments concerned with preparing feasibility studies for projects

- Setting specific standards that correspond to the nature of work within the organizational structure

- Setting specific criteria when selecting leadership styles that are capable of productivity and investment

- A selection of specialized cadres in proportion to the size and needs of work in the project

\section{4- Restructuring of activities and services, represented in the necessity of:}

- Existence of coordination when making plans through interim steps

- Continuous development of activities and services provided using modern and technological devices

- Exploiting the potentials and construction spaces for investment

- Benefiting from the successful administrative experiences in the private sector in investment

- Developing regulations and systems to facilitate the conduct of administrative, financial and legal work

- Develop promotional plans for existing projects and market them appropriately

\section{References in Arabic- :}

1- Ibrahim Mohamed Ahmed "Restructuring and marketing the administrative role of the state in light of the strategic management of change"

Book, University House for Publishing and Distribution ,Alexandria (2011)

2- Ehab Mohamed Jalal, "Modern Management System in Scientific and Practical Foundations, "Kitab, The Modern Arab Library ‘Alexandria (2010)

3- Hanan Ahmed Al-Jamal, "An Organizational Structure for Managing

Strategic Planning in Sports Clubs ," Master Thesis

Faculty of Physical Education, Boys University of Alexandria(2018) 
4- Rashwan Osama Ahmed Abdel Salam "Restructuring the directorates of youth and sports as an entry point for developing administrative performance

At the Ministry of Youth and Sports " PhD thesis, College of Physical Education for Girls ,Alexandria University(2008)

5- Sameh Suleiman Badr "Building a proposed organizational structure for the Sports Marketing Department at the Egyptian Army Stadium in Burj

Al-Arab "MA Thesis, Faculty of Physical Education for Boys , University of Alexandria (2014)

6- Said Abdel-Aziz Othman, "Feasibility Studies of Projects" Kitab ,University Publishing House, Alexandria ( 2013 )

7- Syed Yusef Hazin, "The Strategic Framework for the Development of Sports Development Centers ",Master Thesis, College of Education

Athletic, Helwan University (2014)

8- Amr Mohamed Shawky "Developing the organizational structure of the Directorate of Youth and Sports in Alexandria from an administration perspective Total Quality "Master Thesis , Faculty of Physical Education for Boys, University of Alexandria (2012)

9- Ola Mahmoud Abdel Salam "Building an organizational structure for the management of crises and disasters in sports clubs"

Master Thesis, Faculty of Physical Education for Boys, University of Alexandria (2016)

10- Mustafa Kamel Jaber Ahmed "A proposed project for the management of sports facilities under the partial privatization system in

Light marketing competitiveness directorates of youth and sports in the Arab Republic of Egypt "message

$\mathrm{Ph}$. D ,.Faculty of Physical Education ,Assiut University (2016)

11- Moataz Mustafa Shiha, "Contemporary Administrative Entrance to Sports Institutions Investment, " $\mathrm{PhD}$ thesis,

Faculty of Physical Education for Girls ,Alexandria University(2008)

12- Moamen Abdel Aziz Abdel Hamid, "Organizational Behavior in the Sports Field, "Kitab , Dar Al Ilm and Iman

For publication and distribution, Kafr El-Sheikh (2015)

13- Nabih Al-Alqami, Kamal Al-Din Darwish, Majed Farghaly, Muhammad Fadlallah, "The Economics of Sport and Nationalism"

The State" Kitab, The Book Center for Publishing (2012)

14- Heba Abdel-Azim El-Husseini, "A strategy for restructuring human resources as an entry point to improve the competitive position"

Master Thesis, Faculty of Commerce ,Port Said University (2011) 


\section{References in the foreign language- :}

15- Alex S. Brown, PMP 2012 "Project Management Strategy" Netherlands University

16- Nick John (2010) “ Impact of organizational structure and job characteristics on job satisfaction " University of london

17- Rodney Overton 2007 "Feasibility Studies Made Simple" Australia: Martin Books

18- Shu - HuiPui -Lai 2010 "How knowledge management mediates the relationship between the environment and the organizational structure" New Jersy University

\section{Third: International information network sites- :}

19- http://www.emss.gov.eg/

20- Www.rurdev.usda.gov/rbs/coops/csdir.htm 